or the covering over the entrance to the infested single seed less impenetrable than they were made by the larvæ. The action of the cotton gins may result in loosening the silk spun by the larvæ sufficiently to allow for the entrance of the mites.

Any larvæ that come out of the seed in a mass of seed where Pediculoides occurs abundantly are almost certain to be attacked and killed by this mite, especially late in the season.

The two principal natural enemies are then Pimpla and Pediculoides. Pimpla occurs in some numbers but the bollworm campaign in Egypt should result in all the bolls remaining in the field after the crop being destroyed before the time of the greatest emergence of the parasite, and Pediculoides occurs in numbers only in the storehouses later in the season. When the ginneries are equipped with machines for treating the seed as it leaves the gins, the predaceous mite will cease to be of any importance in connection with the control of pink bollworm in cotton seed.

\title{
NOTES ON THE WOOLLY APHIS
}

By Geo. G. Becker, Fayetteville, Ark.

Owing to the war and to the uncertainty of concluding investigations as planned, the writer is submitting in this paper the results of investigations with the woolly aphis, Eriosoma lanigera Haus., which had as their aim (1) the working out of the life-history of the insect in the Ozarks, (2) studying the relative immunity of various hosts of this insect and of the relationship of these hosts to the species, (3) studying the immunity of Northern Spy stock to the attacks of this species, and (4) determining whether Eriosoma cratogi Oestlund is a synonym of Eriosoma lanigera Hausmann.

In the Ozarks the species winters on elm in the egg stage and on the roots of apple and in wounds, knots and rough places on the trunk above the ground, of apple and Cratægus as apterous vivipariæ. The occurrence of overwintering apterous vivipariæ above ground on apple or Cratægus is uncommon in this latitude as the aphids seem unable to withstand the low temperatures.

The overwintering eggs on elm probably hatch sometime between the first and the middle of March. In 1916 we found stem-mothers in about the third instar by the 30th of March. At this time the buds, with the exception of the infested ones, had not pushed through.

The second generation begins to make its appearance by the first. of April. In 1915 a stem-mother was found on April 20 with about. 20 or more young, in 1916 we found a stem-mother on April 6 with 
about 15 young and in 1917 we found stem-mothers on April 14 with colonies of young.

The third generation probably makes its appearance a little after the middle of April or possibly even sooner.

In 1915 we observed the mature winged individuals of this generation on May 5. In 1916 we observed a colony on May 12 in which 25-50 per cent of the individuals were winged. In 1917 we found the first winged individuals as early as April 27. Under optimum conditions winged individuals from elm might be found from this time on until nearly the last of July. We have found them as late as July 21. Parasites usually cut this generation short so that under normal conditions it is difficult to find the species on elm after the first week of June.

We have not worked out the number of generations of aerial apterous vivipariæ occurring on Cratægus and apple. Fall migrants make their first appearance with us by the middle of September and in favorable seasons may be found as late as the middle of November. There would thus be a period of five months between the appearance of the first spring migrants and the first fall migrants and a period of four months between the last spring migrants and the first fall migrants. If the aerial vivipariæ mature in the same time that the root forms mature (15-25 days), there would certainly be time for the development of more than two generations as recorded for Maine by Miss Patch ${ }^{1}$ and for Vienna, Va., by A. C. Baker. ${ }^{2}$

On the roots of apple the apterous vivipariæ become active by the first of March and continue active until along in November. From the data which we have, this would make it possible for six to twelve generations to develop during the course of a year.

\section{Experiments with SPRINg Migrants}

With a view of determining whether the young of individual migrants would establish on either elm, Cratægus or apple, a series of experiments was begun in which some of the young of each migrant tested was placed on each of the hosts. A safer and more satisfactory method of distributing the young consisted in transferring the migrant from host to host and permitting her to deposit young on each. We found that once a migrant begins to deposit young she usually continues to deposit them in rapid succession until exhausted.

In no case did the offspring of the migrants find elm congenial. In view of the fact that many elms are immune to the insect and that

1 Maine Agricultural Experiment Station Buls. 220 (1913) and 256 (1916).

2 Report No. 101, U. S. Department of Agriculture, Office of the Secretary, 1915. 
on trees not immune aphids establish only under peculiarly favorable conditions, the experiments with elm cannot be regarded as satisfactory.

In these and subsequent experiments young seedling apple trees and young seedlings of Cratogus crus galli were used. Following are the results of experiments with apple and Cratægus.

TABLX I

\begin{tabular}{|c|c|c|c|c|}
\hline & No. Migrants Tested & $\begin{array}{l}\text { No. whose Young Eat. } \\
\text { on Both Hosts }\end{array}$ & $\begin{array}{l}\text { No. whose Younp Est. } \\
\text { on Apple Only }\end{array}$ & $\begin{array}{l}\text { No. whose Young Eat. } \\
\text { on Crstsegus Only }\end{array}$ \\
\hline $\begin{array}{l}1915 \ldots \ldots \ldots \ldots \ldots \ldots \ldots \\
1916 \ldots \ldots \ldots \ldots \ldots \ldots \ldots \\
1917 \ldots \ldots \ldots \ldots \ldots \ldots\end{array}$ & $\begin{array}{r}12 \\
5 \\
18\end{array}$ & $\begin{array}{l}4 \\
0 \\
0\end{array}$ & $\begin{array}{r}1 \\
1 \\
16\end{array}$ & $\begin{array}{l}1 \\
0 \\
0\end{array}$ \\
\hline
\end{tabular}

The above does not give us as much data as we would like but these tests along with other tests not recorded in this paper show the marked immunity of Cratægus as compared with apple. The difference in the results of the three seasons suggests that in addition to an inherent immunity, Cratægus may have a conditional immunity depending upon the season. This is further suggested by our experiments with Cratægus seedlings.

Our spring migrants seemed to be slightly more prolific than Baker's, averaging usually from 7 to 8 per female instead of 6 as reported by Baker for Vienna, Va. One individual under our observation deposited 19 young. Another deposited 18.

\section{Experiments with Elm}

In our observations on elm we were impressed at the earliness with which the stimulative effect of the aphids affected the leaves. It appeared that the aphids must have attacked the leaves almost before they had pushed through the bud or at least just as soon as enough was through for them to work on. At any rate the attacked leaves pushed through and curled at once before the normal buds had pushed out. Terminals where embryo colonies were forming were conspicuous on the trees before the normal buds had burst. In the accompanying plate are pictures of normal and infested buds which were collected from the same tree and at the same time, April 6, 1917.

The difficulty which Baker had in getting this insect to establish on elm was witnessed by us. We tried repeatedly to establish second and third generation larvæ on various potted elms but without success. It was noticed on our campus that there was a marked variation in the immunity of various elms to this insect. Near our insectary we have noticed an elm to be infested every year for the last five years 
and during the same time numbers of elms which are near it have never been observed to be infested.

It appeared from general observation that backwardness of growth was associated with susceptibility to the attacks of the insect. To verify this, $35 \mathrm{elms}$ were examined at random. They were classified according to their size and were rated as advanced, medium and backward, according to the degree of their advancement at the date of the observation, April 8, 1917. The results of the observations appear in Table II.

TABLE II

\begin{tabular}{|c|c|c|c|c|c|c|}
\hline \multirow{2}{*}{ Circum. in Inches } & \multicolumn{2}{|c|}{ Advanced } & \multicolumn{2}{|c|}{ Medium } & \multicolumn{2}{|c|}{ Backward } \\
\hline & Infested & Uninfested & Infested & Uninfosted & Infeeted & Uninfested \\
\hline $\begin{array}{l}20 \text { and ip } \ldots \ldots \ldots \ldots \ldots \ldots \ldots \\
10-20 \ldots \ldots \ldots \ldots \ldots \ldots \ldots \ldots \ldots \ldots \\
5-10 \ldots \ldots \ldots \ldots \ldots \ldots \ldots \ldots \ldots \ldots \ldots\end{array}$ & $\begin{array}{l}1 \\
1 \\
1 \\
\mathbf{0}\end{array}$ & $\begin{array}{l}3 \\
1 \\
3 \\
5 \\
\end{array}$ & $\begin{array}{l}0 \\
1 \\
2 \\
1 \\
\end{array}$ & $\begin{array}{l}0 \\
1 \\
2 \\
5 \\
\end{array}$ & $\begin{array}{l}0 \\
2 \\
2 \\
1 \\
\end{array}$ & $\begin{array}{l}0 \\
0 \\
2 \\
1 \\
\end{array}$ \\
\hline Total. ..... & 3 & 12 & 4 & 8 & 5 & 3 \\
\hline
\end{tabular}

It will be observed that the above seems to bear out this contention. In 1915 we observed a small elm, which had been set out the fall before, to be infested. It was presumably congenial to the insect because it was backward during that season. At any rate it has not been observed to be infested since that time.

\section{Experiments with Cratagus}

Many negative results in attempting to get aphids to establish on Cratægus led us to undertake some experiments with a view of determining to what extent this host was immune to the species. Young Cratægus seedlings were used in these tests. Five aphids were applied at a time and we tried to make 10 transfers, making a total of 50 aphids, to each seedling before placing it aside as immune. The aphids used were secured from infested Cratægus plants. The results of these tests appear in Table III.

It will be observed that the first four seedlings tested took colonies. In view of the difficulty of getting colonies to establish later in the season it would appear that the hardening of the tissues would be a condition which would bring about immunity. The seedlings used in experiments $\mathrm{Ca}-\mathrm{C} 17$ to $\mathrm{Ca}-\mathrm{C} 23$ inclusive had been used earlier in the season in the Aa-C series (Table IV), and in those tests were not acceptable to the aphids. They were subsequently cut back and watered with manure water until tender shoots were produced. Under these conditions two of the seedlings were acceptable to the Cratægus aphids. 
Tasu III

\begin{tabular}{|c|c|c|c|c|}
\hline \multirow{2}{*}{ Exp. No. } & \multirow{2}{*}{$\begin{array}{l}\text { Duration of } \\
\text { Experiment }\end{array}$} & \multicolumn{2}{|c|}{ Trangfers } & \multirow{2}{*}{ Results } \\
\hline & & No. & $\begin{array}{l}\text { Totsl Aphids } \\
\text { Appliod }\end{array}$ & \\
\hline 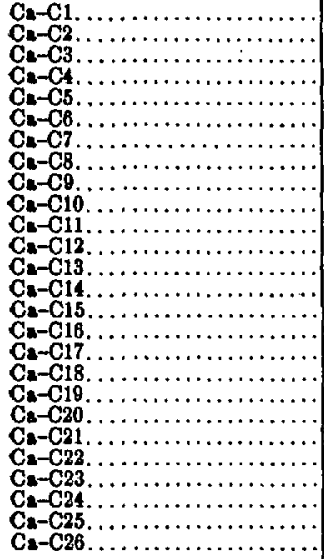 & $\begin{array}{l}7 / 2-10 / 15 \\
7 / 2-11 / 1 \\
7 / 2-8 / 5 \\
7 / 6-8 / 7 \\
7 / 18-8 / 1 \\
7 / 18-8 / 1 \\
7 / 18-8 / 1 \\
7 / 18-7 / 21 \\
7 / 18-7 / 21 \\
7 / 18-8 / 1 \\
7 / 18-8 / 1 \\
8 / 1-8 / 17 \\
8 / 1-8 / 17 \\
8 / 1-8 / 17 \\
8 / 1-8 / 17 \\
8 / 1-8 / 17 \\
8 / 3-9 / 14 \\
8 / 3-8 / 15 \\
8 / 3-9 / 14 \\
8 / 3-8 / 15 \\
8 / 3-9 / 14 \\
8 / 3-9 / 14 \\
8 / 2-9 / 11 \\
8 / 23-8 / 14 \\
8 / 23-9 / 14 \\
8 / 23-9 / 14\end{array}$ & $\begin{array}{r}1 \\
1 \\
6 \\
9 \\
9 \\
10 \\
10 \\
2 \\
3 \\
10 \\
10 \\
12 \\
9 \\
11 \\
9 \\
9 \\
6 \\
1 \\
12 \\
1 \\
5 \\
14 \\
5 \\
1 \\
2 \\
7\end{array}$ & $\begin{array}{r}5 \\
5 \\
30 \\
45 \\
45 \\
50 \\
50 \\
10 \\
15 \\
50 \\
50 \\
60 \\
45 \\
55 \\
45 \\
45 \\
30 \\
5 \\
60 \\
5 \\
25 \\
70 \\
25 \\
5 \\
10 \\
35\end{array}$ & 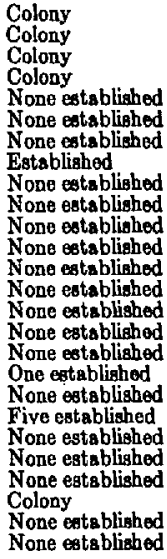 \\
\hline
\end{tabular}

From these experiments and from our general experience with the species we conclude;

(1) That through being continuously subjected to the attacks of the woolly aphis Cratægus has acquired a strong immunity against this pest.

(2) That this immunity is inherent or it may be conditional, depending upon factors which influence the character of its growth.

\section{Experiments in Transferring Cratagus Aphids to Apple and VICE VERSA}

As early as 1910 Hayhurst, thinking that there might be two races of lanigera, one on apple and one on Cratægus, made attempts to establish the Cratægus forms on apple and vice versa. His results were all negative. The writer repeated the experiments in 1911 with the same results and in $1913 \mathrm{Mr}$. Quick, a student assistant, made the same attempt and succeeded in getting a few Cratægus aphids to establish imperfectly on apple. In view of the immunity of most Cratægus seedlings at the time (in late summer), when all of these tests were made, the results were not surprising.

In $1917 \mathrm{Mr}$. William Lee, a student assistant working under the writer's direction, repeated the tests and included in his experiments Cratægus seedlings which he had previously found to be congenial to Cratægus aphids. His results are given in Table IV. Aa-C17 to 
Aa-C23 inclusive were found to be congenial to Cratægus forms in the $\mathrm{Ca}-\mathrm{C}$ tests (Table III). Under "remarks" is given the number of these seedlings in the Ca-C tests of Table III.

TABLI IV

\begin{tabular}{|c|c|c|c|c|c|}
\hline \multirow{2}{*}{ Exp. No. } & \multirow{2}{*}{$\begin{array}{l}\text { Duration of } \\
\text { Experiment }\end{array}$} & \multicolumn{2}{|c|}{ Transferg } & \multirow{2}{*}{ Results } & \multirow{2}{*}{ Remarka } \\
\hline & & No. & $\begin{array}{c}\text { Tote]Aphids } \\
\text { Applied }\end{array}$ & & \\
\hline 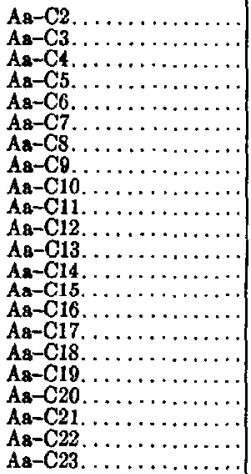 & $\begin{array}{l}6 / 15-7 / 12 \\
6 / 15-7 / 12 \\
6 / 15-7 / 12 \\
6 / 15-7 / 12 \\
6 / 15-7 / 12 \\
7 / 13-7 / 26 \\
713-7 / 26 \\
7 / 13-7 / 26 \\
7 / 13-7 / 26 \\
7 / 13-7 / 26 \\
7 / 20-7 / 31 \\
7 / 20-7 / 31 \\
7 / 20-7 / 31 \\
7 / 20-7 / 31 \\
7 / 20-7 / 31 \\
7 / 31-8 / 14 \\
8 / 6-8 / 23 \\
8 / 15-9 / 14 \\
8 / 15-11 / 15 \\
9 / 14-10 / 5 \\
10 / 5-10 / 13 \\
10 / 15-11 / 14\end{array}$ & $\begin{array}{r}10 \\
12 \\
12 \\
13 \\
11 \\
10 \\
10 \\
11 \\
10 \\
11 \\
10 \\
10 \\
10 \\
10 \\
10 \\
18 \\
4 \\
13 \\
1 \\
2 \\
1 \\
2\end{array}$ & $\begin{array}{r}50 \\
60 \\
60 \\
65 \\
55 \\
50 \\
50 \\
55 \\
50 \\
55 \\
50 \\
50 \\
50 \\
50 \\
50 \\
83 \\
20 \\
65 \\
5 \\
25 \\
20 \\
35\end{array}$ & 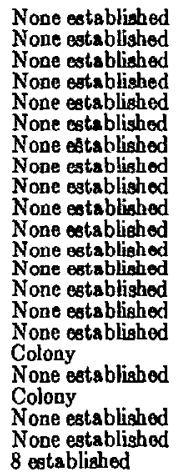 & $\begin{array}{c}\ldots \\
\ldots \\
\ldots \\
\ldots \\
\ldots \\
\ldots \\
\ldots \\
\ldots \\
\ldots \\
\ldots \\
\ldots \\
\ldots \\
\ldots \\
\ldots \\
\ldots \\
\text { Was Ca-C3 } \\
\text { Was Ca-C8 } \\
\text { Was Ca-C18 } \\
\text { Was Ca-C20 } \\
\text { Was Ca-C24 } \\
\text { Was Ca-C25 } \\
\text { Was Ca-C1 }\end{array}$ \\
\hline
\end{tabular}

It should be stated in the case of $\mathrm{Aa}-\mathrm{C} 23$, which was $\mathrm{Ca}-\mathrm{C} 1$ of Table III, that it was brought into the tests at a time when it was beginning to shed its leaves. Aphids established on it and produced young though the latter did not establish. When the latter were born practically all the leaves had been shed and the tissues are bound to have hardened.

Further trials were made by attempting to establish apterous vivipariæ from Cratægus on apple with the results indicated in Table V.

TABLE V

\begin{tabular}{|c|c|c|c|c|}
\hline \multirow{2}{*}{ Exp. No. } & \multirow{2}{*}{$\begin{array}{l}\text { Duration of } \\
\text { Experiment }\end{array}$} & \multicolumn{2}{|c|}{ Transfers } & \multirow{2}{*}{ Resulte } \\
\hline & & No. & $\begin{array}{l}\text { Total Aphids } \\
\text { Applied }\end{array}$ & \\
\hline 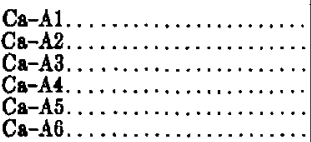 & $\begin{array}{l}7 / 16-9 / 14 \\
8 / 2-9 / 14 \\
8 / 2-11 / 1 \\
8 / 2-9 / 14 \\
8 / 2-11 / 1 \\
10 / 15-11 / 1\end{array}$ & $\begin{array}{r}18 \\
12 \\
13 \\
18 \\
14 \\
2\end{array}$ & $\begin{array}{r}88 \\
60 \\
65 \\
90 \\
66 \\
3\end{array}$ & $\begin{array}{l}\text { None establiahed } \\
\text { None establiahed } \\
\text { Colony } \\
\text { None establiahed } \\
\text { Colony } \\
\text { None eatsblished }\end{array}$ \\
\hline
\end{tabular}

The apple seedlings used in the tests given in Table $\mathrm{V}$ were tested and found to be congenial to apple aphids. 
The results of our transfer experiments lead us to the conclusion:

(1) That apterous vivipariæ from apple can establish on Cratægus though they do not establish on that host as readily as they do on apple.

(2) That apterous vivipariæ from Cratægus can establish on apple though they apparently do not establish as readily on that host as do the apterous vivipariæ from apple.

\section{NorThern SPY IMMUNITY}

Aside from experiments undertaken with Northern Spy roots no definite experiments were undertaken to see to what extent different apple seedlings were immune to the woolly aphis. It might be stated however, from general experience, that we noticed a difference in the degree of immunity of different apple seedlings. Generally speaking, though, we had no difficulty in establishing either the offspring of spring migrants or of apterous vivipariæ from other apple seedlings on this host.

In these tests pieces of Northern Spy root were placed in tin salve boxes and handled in the same manner as described for our experiments with the apple root forms. Five aphids were applied to each piece of root and when these had died another attempt was made to establish a colony by adding, five more aphids. The aphids used were usually of the first instar and were taken from crab roots.

We made 161 attempts to establish colonies on Northern Spy roots, using a total of 805 aphids. Of the 161 attempts we got colonies to establish temporarily in 16 instances. In two of the trials we succeeded in getting the aphids to establish long enough to produce young but the latter failed to establish permanently. In no case did we succeed in getting permanent colonies to establish on Northern Spy roots.

As a check against these results we made 51 trials to establish aphids on crab roots, using in the tests 255 aphids. Twenty-seven of the trials yielded colonies. In most instances these colonies were permanent.

Most of these tests were made by my student assistants, Messrs. W. D. Merrill and Wm. M. Lee, and their notes repeatedly call attention to the sickly condition of the temporary colonies on Northern Spy as compared with the thrifty colonies on crab roots.

From these tests we conclude that Northern Spy is immune to the woolly aphis and that, when aphids do establish temporarily, it is due to the fact that they are exceptionally hardy rather than the fact that the host is congenial. 


\section{. Experiments with Apple Root Forms}

Experiments were begun with a view of working out the duration of the instars, number of young per female, longevity, number of generations per season, etc., of the apple root forms. We got satisfactory results by using tin salve boxes in the bottom of which we poured paraffin mixed with lamp black. This enabled us to detect aphids or exuviæ which had fallen on the bottom of the box. Pieces of root were wrapped at one end with moist cotton batting and the other end was left exposed for the aphids. The boxes were sunk in soil out of doors and were covered with a board.

Records of 40 aphids made by my predecessor, Mr. Paul Hayhurst, during March and April of 1910 are summarized in Table VI.

The days for each instar are given. Duration of the fifth instar is practically the same as the period of reproduction as aphids almost invariably begin to reproduce on the same day that they moult the fourth time. The number of days from birth to the first young will therefore generally be the same as the combined number of days of the first four instars. The age at death is expressed in days.

TABLE VI

\begin{tabular}{|c|c|c|c|c|c|c|c|c|c|}
\hline & $\begin{array}{c}\text { Days 18t } \\
\text { Ingtar }\end{array}$ & $\begin{array}{c}\text { Days 2nd } \\
\text { Instar }\end{array}$ & $\begin{array}{l}\text { Days 3rd } \\
\text { Instar }\end{array}$ & $\begin{array}{c}\text { Days 4th } \\
\text { Instar }\end{array}$ & $\begin{array}{c}\text { Days 5th } \\
\text { Instar }\end{array}$ & $\begin{array}{l}\text { Daysto } \\
\text { Young }\end{array}$ & $\begin{array}{l}\text { Max. Yng. } \\
\text { per Day }\end{array}$ & $\underset{\text { Young }}{\text { Totsl' }}$ & $\begin{array}{l}\text { Age at } \\
\text { Desth }\end{array}$ \\
\hline $\begin{array}{l}\text { Average. ......... } \\
\text { Range.......... }\end{array}$ & $\begin{array}{c}7.3 \\
\ldots .3-14\end{array}$ & $\begin{array}{l}3.9 \\
2-7\end{array}$ & $\begin{array}{l}3.2 \\
1-6\end{array}$ & $\begin{array}{l}3.8 \\
1-8\end{array}$ & $\begin{array}{l}22.6 \\
5-47\end{array}$ & $\begin{array}{r}18.8 \\
15-25\end{array}$ & $\begin{array}{l}11.5 \\
2-23\end{array}$ & $\begin{array}{r}86.3 \\
8-167\end{array}$ & $\begin{array}{r}40.2 \\
21-59\end{array}$ \\
\hline
\end{tabular}

If the aphids develop on the roots of apple under normal conditions as well as in the salve boxes and if later generations develop as rapidly as the generations in March and April, it would appear that it would be possible for 6 to 12 generations to develop from March to November, which period is the period of activity of the root forms in this latitude.

\section{Experiments with Fall Migrants}

In 1915,1916 and 1917 we made numerous attempts to get fall migrants to deposit sexupariæ on Cratægus, apple and elm seedlings under cage conditions. Migrants were placed in cages of varying sizes with these seedlings and with large limbs from elms but we failed to get the sexed forms in 1915 and 1916. During the same period we also tried placing seedlings of its three hosts in the window and releasing the migrants in a dark corner of the laboratory. Although the migrants made their way to the seedlings they failed to deposit young on them. In 1917 we succeeded in getting migrants to deposit the sexed forms by confining them in large vials and under glass cylinders with rough pieces of elm bark, however, we failed to get any eggs from the sexed forms, 
Eriosoma cratagi Oestlund

Mounts were made of the fall migrants of Eriosoma lanigera secured from different sources (apple and Cratægus), with a view of determining the effect of the host on the antennæ of the aphids. The results are tabulated in Table VII. The table gives the measurements of the segments in mm. The number of annulations of the segments is also given.

The following explanation is given for the slide numbers.

Slide 1.-From control colony on apple reared from a spring migrant in 1917 .

Slide 2.-From a control colony on Cratæegus reared from a spring migrant in 1915.

Slides $S$ and 4.-From colonies on potted apple trees which were presumably started by spring migrants in 1917 .

Slide 5.-From the same source as Slide 2.

Slide 6.-From apple colony established by transferring apterous vivipariæ from Cratagus in 1917. (Colony Ca-A5 of Table V.)

Slides 7 to 11 inclusive.-From Cratægus colonies established by transferring apterous vivipariæ from apple in 1917. (Colonies Aa-C18 and Aa-C20 of Table IV.)

TABLI VII

\begin{tabular}{|c|c|c|c|c|c|c|c|c|c|c|}
\hline \multirow{2}{*}{$\begin{array}{l}\text { Slide } \\
\text { No. }\end{array}$} & \multirow{2}{*}{$\frac{I}{\text { Mess. }}$} & \multirow{2}{*}{$\frac{\text { II }}{\substack{\text { Mear. } \\
\text { in mm. }}}$} & \multicolumn{2}{|c|}{ III } & \multicolumn{2}{|c|}{ IV } & \multicolumn{2}{|c|}{ V } & \multicolumn{2}{|c|}{ VI } \\
\hline & & & $\begin{array}{l}\text { Meas. } \\
\text { in mm. }\end{array}$ & $\begin{array}{l}\text { An. } \\
\text { No. }\end{array}$ & $\begin{array}{l}\text { Meas. } \\
\text { in mm. }\end{array}$ & $\begin{array}{l}\text { An. } \\
\text { No. }\end{array}$ & $\begin{array}{l}\text { Meas. } \\
\text { in mm. }\end{array}$ & $\begin{array}{l}\text { An. } \\
\text { No. }\end{array}$ & $\begin{array}{l}\text { Mess. } \\
\text { in mmn. }\end{array}$ & $\begin{array}{l}\text { An. } \\
\text { No. }\end{array}$ \\
\hline $\begin{array}{r}1 \\
1 \\
2 \\
3 \\
3 \\
3 \\
3 \\
4 \\
4 \\
4 \\
5 \\
5 \\
5 \\
6 \\
6 \\
6 \\
6 \\
7 \\
8 \\
8 \\
8 \\
9 \\
9 \\
9 \\
9 \\
10 \\
10 \\
11 \\
11\end{array}$ & $\begin{array}{l}.068 \\
.061 \\
.061 \\
.059 \\
.006 \\
\ldots .056 \\
\ldots .058 \\
.059 \\
.064 \\
\ldots \ldots \\
.056 \\
.051 \\
\ldots \ldots \\
.051 \\
\ldots \ldots \\
\ldots . \\
.064 \\
.064 \\
.054 \\
\ldots \ldots \\
.058 \\
\ldots \ldots\end{array}$ & $\begin{array}{l}.073 \\
.065 \\
.064 \\
.056 \\
.064 \\
.064 \\
.064 \\
.064 \\
.066 \\
.060 \\
.064 \\
.056 \\
.051 \\
.053 \\
.061 \\
\ldots .056 \\
.051 \\
\ldots \ldots \\
\ldots .04 \\
.064 \\
.064 \\
.061 \\
.061 \\
.061 \\
.064 \\
.056 \\
.056\end{array}$ & $\begin{array}{l}.416 \\
.415 \\
.432 \\
.320 \\
.335 \\
.382 \\
.365 \\
.400 \\
.400 \\
.365 \\
.455 \\
.440 \\
.462 \\
.342 \\
.343 \\
.343 \\
.375 \\
.400 \\
.420 \\
.368 \\
.405 \\
.420 \\
.430 \\
.431 \\
.430 \\
.430 \\
.440\end{array}$ & $\begin{array}{l}22 \\
26 \\
27 \\
16 \\
18 \\
20 \\
20 \\
21 \\
20 \\
18 \\
28 \\
27 \\
29 \\
20 \\
20 \\
18 \\
23 \\
24 \\
24 \\
25 \\
\cdots \\
27 \\
27 \\
27 \\
28 \\
27 \\
25 \\
25 \\
28\end{array}$ & $\begin{array}{l}.124 \\
.112 \\
.124 \\
.108 \\
.072 \\
.130 \\
.131 \\
.112 \\
.128 \\
.112 \\
.120 \\
.112 \\
.120 \\
.096 \\
.120 \\
.110 \\
.088 \\
.120 \\
.120 \\
.131 \\
.112 \\
.112 \\
.112 \\
.135 \\
.128 \\
.128 \\
.135 \\
.120 \\
.128\end{array}$ & $\begin{array}{l}5 \\
6 \\
5 \\
4 \\
3 \\
7 \\
6 \\
4 \\
5 \\
5 \\
6 \\
6 \\
6 \\
3 \\
4 \\
3 \\
3 \\
5 \\
7 \\
6 \\
5 \\
7 \\
7 \\
7 \\
7 \\
6 \\
7 \\
6 \\
6\end{array}$ & $\begin{array}{l}.124 \\
.112 \\
.146 \\
.112 \\
.120 \\
.126 \\
.128 \\
.128 \\
.120 \\
.115 \\
.141 \\
.120 \\
.144 \\
.110 \\
.123 \\
.123 \\
.100 \\
.128 \\
.131 \\
.152 \\
.152 \\
.148 \\
.156 \\
.152 \\
.152 \\
.160 \\
.160 \\
.155 \\
.148\end{array}$ & $\begin{array}{r}7 \\
6 \\
8 \\
5 \\
5 \\
6 \\
5 \\
7 \\
5 \\
5 \\
7 \\
7 \\
\mathbf{8} \\
5 \\
6 \\
6 \\
5 \\
6 \\
7 \\
10 \\
8 \\
8 \\
8 \\
8 \\
10 \\
7 \\
8 \\
8 \\
9\end{array}$ & $\begin{array}{l}.088 \\
.084 \\
.085 \\
.085 \\
.092 \\
.096 \\
.092 \\
.088 \\
.098 \\
.086 \\
.096 \\
.104 \\
.112 \\
.090 \\
.072 \\
.083 \\
.112 \\
.112 \\
.115 \\
.115 \\
.112 \\
.112 \\
.112 \\
.112 \\
.115 \\
.118 \\
.096 \\
.112\end{array}$ & $\begin{array}{l}0 \\
0 \\
1 \\
2 \\
1 \\
2 \\
0 \\
0 \\
1 \\
0 \\
2 \\
2 \\
2 \\
1 \\
1 \\
1 \\
2 \\
3 \\
4 \\
3 \\
5 \\
3 \\
3 \\
4 \\
3 \\
3 \\
3 \\
2 \\
2\end{array}$ \\
\hline
\end{tabular}

It appears from a study of the 13 antennæ of apple migrants and the 16 antennæ of Cratægus migrants that the antennæ of the latter are usually longer than those of the apple migrants. Especially is this the case in segments III, V and VI. For convenience the writer has 
averaged the antennæ of migrants of the two hosts separately and collectively in Table VIII. The wide range of variation in the antenno of Eriosoma lanigera is well shown in the range for the 29 antennæ measured. It is such that it might well embrace the measurements given for Eriosoma cratcegi by Davis in Volume 3, No. 5 of this JOURNAL.

TABLD VIII

\begin{tabular}{|c|c|c|c|c|c|c|c|c|c|c|}
\hline & \multirow{2}{*}{$\frac{I}{\text { Meas. }}$} & \multirow{2}{*}{$\begin{array}{c}\text { II } \\
\text { Mess. } \\
\text { in mm. }\end{array}$} & \multicolumn{2}{|c|}{ III } & \multicolumn{2}{|c|}{ IV } & \multicolumn{2}{|l|}{ V } & \multicolumn{2}{|c|}{ VI } \\
\hline & & & $\begin{array}{l}\text { Meas. } \\
\text { in mm. }\end{array}$ & An. & $\begin{array}{l}\text { Moss. } \\
\text { in } \mathrm{mm} .\end{array}$ & An. & $\begin{array}{l}\text { Meas. } \\
\text { in } \mathrm{mm} .\end{array}$ & $\begin{array}{l}\text { An. } \\
\text { No. }\end{array}$ & $\begin{array}{l}\text { Mens. } \\
\text { in mr. }\end{array}$ & An. \\
\hline \multicolumn{11}{|c|}{ Thirteen Antenna from Apple Migrants } \\
\hline $\begin{array}{l}\text { Aversge....... } \\
\text { Minimum..... } \\
\text { Maximum.... }\end{array}$ & $\begin{array}{l}.059 \\
.051 \\
.068\end{array}$ & $\begin{array}{l}.062 \\
.051 \\
.073\end{array}$ & $\begin{array}{l}.369 \\
.320 \\
.416\end{array}$ & $\begin{array}{l}20 \\
16 \\
22\end{array}$ & $\begin{array}{l}.111 \\
.088^{*} \\
.131\end{array}$ & $\begin{array}{l}1 \\
3 \\
7 \\
7\end{array}$ & $\begin{array}{l}.119 \\
100 \\
.128\end{array}$ & $\begin{array}{l}6 \\
5 \\
7\end{array}$ & $\begin{array}{l}.087 \\
.072 \\
.006\end{array}$ & $\begin{array}{l}1 \\
0 \\
2\end{array}$ \\
\hline \multicolumn{11}{|c|}{ Sixteen Antennx from Crategus Migrsnts } \\
\hline $\begin{array}{l}\text { Avarage. . .... } \\
\text { Minimum. . . } \\
\text { Maximum.... }\end{array}$ & $\begin{array}{l}.060 \\
.051 \\
.064\end{array}$ & $\begin{array}{l}.060 \\
.051 \\
.064\end{array}$ & $\begin{array}{l}.423 \\
.368 \\
.462\end{array}$ & $\begin{array}{l}27 \\
24 \\
29\end{array}$ & $\begin{array}{l}.122 \\
.112 \\
.135\end{array}$ & $\begin{array}{l}6 \\
5 \\
7\end{array}$ & $\begin{array}{l}.147 \\
.120 \\
.160\end{array}$ & $\begin{array}{r}8 \\
6 \\
10\end{array}$ & $\begin{array}{l}.109 \\
.085 \\
.118\end{array}$ & $\begin{array}{l}3 \\
0 \\
5\end{array}$ \\
\hline \multicolumn{11}{|c|}{ Thirteen Antenno from Apple and Sirteen Antennse from Cratugus Migrant } \\
\hline $\begin{array}{l}\text { Average. ...... } \\
\text { Minimum.... } \\
\text { Maximum. . . }\end{array}$ & $\begin{array}{l}.060 \\
.051 \\
.068\end{array}$ & $\begin{array}{l}.061 \\
.051 \\
.073\end{array}$ & $\begin{array}{l}.389 \\
.320 \\
.462\end{array}$ & $\begin{array}{l}23 \\
16 \\
29\end{array}$ & $\begin{array}{l}.117 \\
.088^{*} \\
.135\end{array}$ & $\begin{array}{l}\mathbf{5} \\
3 \\
7\end{array}$ & $\begin{array}{l}.134 \\
.100 \\
.160\end{array}$ & $\begin{array}{r}7 \\
5 \\
10\end{array}$ & $\begin{array}{l}.099 \\
.072 \\
.118\end{array}$ & $\begin{array}{l}2 \\
0 \\
5\end{array}$ \\
\hline
\end{tabular}

The smallest segment IV was on slide 3 . It measured .072 but appeared somewhat abnormal.

\section{Explanation of Plate 6}

1 and 2. Antennæ from migrants out of control colony on apple established from the offspring of a spring migrant.

3. Antenna from fall migrant taken from colony on potted apple tree.

4. Antenna from fall migrant out of colony established on apple with apterous vivipariæ from Cratægus. (Colony $\mathrm{Ca}-\mathrm{A} 5$ of Table V.)

5. Antenna from fall migrant out of control colony established on Cratægus from spring migrant.

6-8 inclusive. Antennæ from fall migrants out of colonies established on Cratregus with apterous vivipariæ from apple. (Colonies Aa-C18 and Aa-C20 of Table VI.)

- 9. Antenna of fall migrant of Eriosoma cratagi taken from mount loaned me by A. C. Baker.

The two lower pictures represent normal and infested elm buds collected at the same time, April 6, 1917 and from the same tree. 


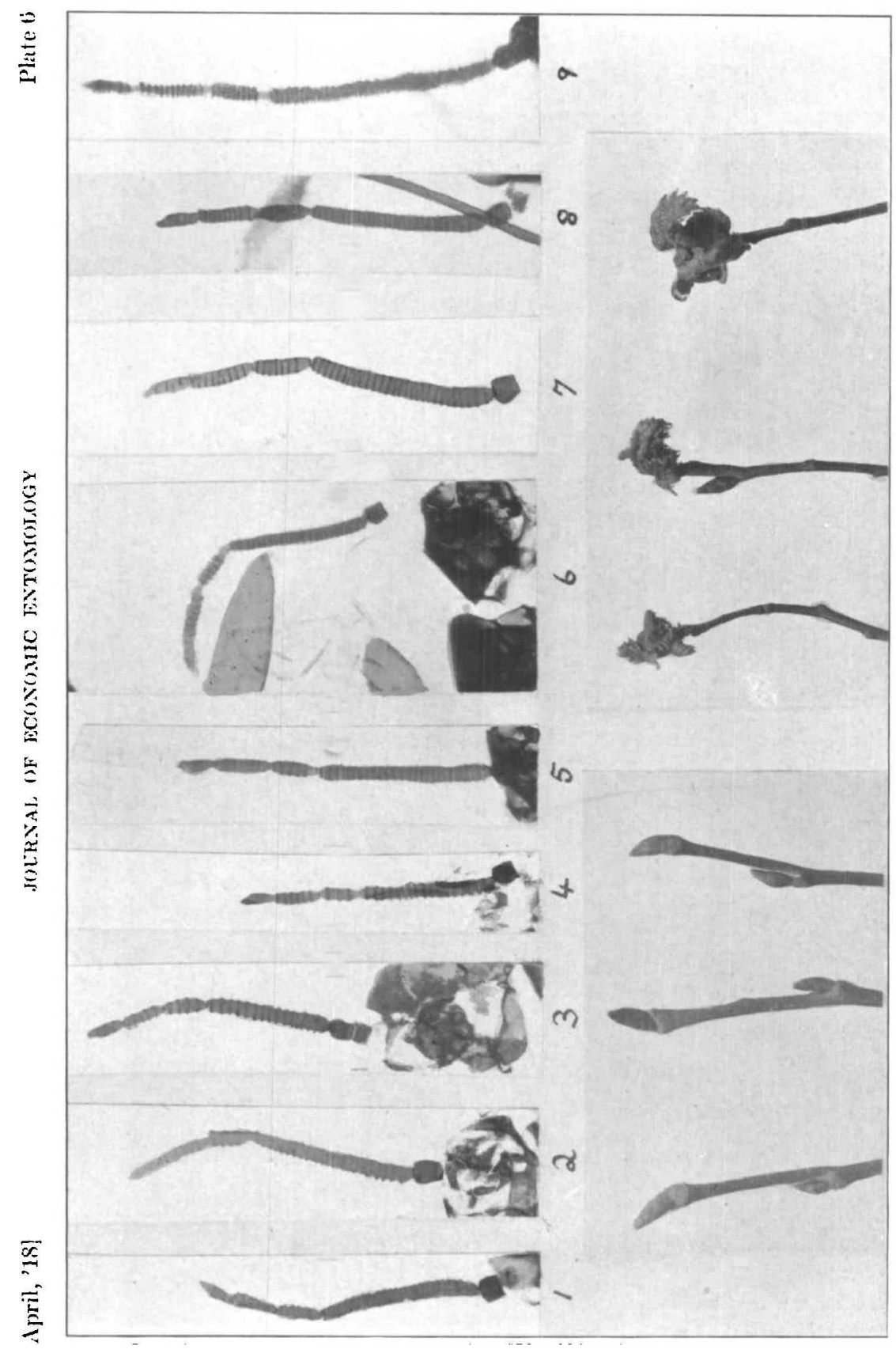

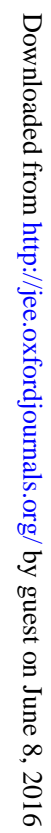


Baker, ${ }^{1}$ in suggesting that Eriosoma cratogi is a synonym of Eriosoma lanigera, pointed out that the principal difference between the species was in segments V and VI which were proportionately longer in the former species. As previously indicated, our data show that these two segments are proportionately longer in our Cratægus reared aphids.

Through the courtesy of Mr. Baker the writer was permitted to examine a mount of cratcei migrants. A photograph was taken of a typical antenna of this species and photographs of lanigera migrants were made in comparison. All are taken at the same magnification (about $48 \mathrm{X}$ ), and are represented in the accompanying plate. It will be noticed that Nos. 5 and 8, antennæ from Cratægus reared aphids, are strikingly similar to the antenna of cratcogi, figured in 9 .

If measurements and structural differences are to be used as a basis for dividing them, it would hardly be possible for us to regard cratcegi and lanigera as two species.

\section{Conclusions}

(1) The life-history of Eriosoma lanigera in the Ozarks is the same as recorded for Maine and for Vienna, Va., with the exception that there are probably more than two generations of apterous vivipariæ on apple and Cratægus.

(2) Experiments with apple root forms indicate that there may be from six to twelve generations a year in the Ozarks.

(3) Elms have acquired a strong degree of immunity against this species. Susceptibility to attack seems to be correlated with backwardness of growth in the spring.

(4) Cratcous crus galli is largely immune to the insect, the condition of immunity being apparently inherent in some instances and conditional in others.

(5) Northern Spy stock is immune to the species.

(6) Apterous vivipariæ from Cratægus will establish on apple and apterous vivipariæ from apple will establish on Cratægus though the Cratægus individuals do not establish as readily on apple as do the individuals from the same host.

(7) Based on a study of the antennæ, the writer's data indicate that Eriosoma cratagi Oestlund is a synonym of Eriosoma lanigera Hausmann.

${ }^{1}$ Report No. 101, U. S. Department of Agriculture, Office of the Secretary, 1915. 